\title{
6 The decline of Nordic social democracy
}

Kjell Östberg

\section{Social democracy's present crisis}

Social democracy has generally been considered one of the most successful political forces of the 1900s. In particular, the 30 post-war "golden years" - the century's most prosperous period - have been closely associated with social democracy and seen as the standard bearer of modernization and the solidaric welfare society. The Nordic countries have taken an obvious leading position in this development and are viewed in a special light. ${ }^{1}$ The Nordic model, building on the institutionalized, corporatist collaboration between capital, labour and state and long extolled as a successful compromise between a communist planned economy and free market capitalism, has close links to Nordic social democracy.

Twenty years ago, social democracy was Europe's leading force. Its leaders were Gerhard Schröder, Tony Blair, Lionel Jospin - and Nordic leaders Göran Persson, Paavo Lipponen, Jens Stoltenberg and Poul Nyrup Rasmussen. Twelve of the prime ministers who made up the Council of the European Union were Social Democrats, and the so-called Third Way promised to give answers to the challenges of a globalized society. ${ }^{2}$

The organizational home of Nordic social democracy has been the Social Democratic parties; working-class dominated mass parties with deep roots in trade unions and popular movements. Today, international social democracy is in deep crisis, ideologically, politically and organizationally. In recent years, Social Democrats have suffered dramatic defeats in a series of parliamentary elections. The German Social Democratic Party, which for long periods of time has been the most powerful in Europe, has been overshadowed by Angela Merkel since 2005. In the fall election of 2017, it lost 5 per cent of its votes, ending up at a record low of 20 per cent. In the European election of 2019, it sank to 15 per cent. The French socialists had a catastrophic election in 2017, getting a mere 6 per cent of the votes in the presidential election; their mandates in the national assembly dropped from 280 to 30 . In the Netherlands, the party went from 25 per cent of the vote to 5.7 per cent. In Austria in 2016, the social-democratic presidential candidate received 11 per cent of the votes and was defeated in the first round. 
Nordic social democracy, long viewed as the jewel in the crown of international social democracy, is no longer an exception. ${ }^{3}$ It is true that Sweden, Finland and Denmark in the summer of 2019 have Social Democratic prime ministers, but the election support for all three is at a historic low. In Sweden, the Social Democratic Party has lost 40 per cent of its voters and two-thirds of its members over the last decades. To be able to lead a fragile coalition government together with the Green Party, the Swedish Social Democrats were forced to accept harsh political concessions to bourgeois parties, in the same way the Danish party did when it accepted much of the immigration policy of populist and xenophobic Dansk Folkeparti.

This chapter will, by focusing on Sweden, discuss the situation of Nordic social democracy against the backdrop of the developments of recent decades. Despite some clear distinctions between them, the parties will all be seen to share a special Nordic tradition. By way of introduction I will formulate two possible explanations for the development of international social democracy. The analysis will follow two red threads, one political and one organizational.

In the mid-20th century, to follow the political thread, social democracy formulated an objective that found more mass support than any other leftist idea: to offer citizens protection against the inequalities created by an unregulated market. ${ }^{4}$ According to one thesis, social democracy's decline is associated with the fact that it has abandoned this policy.

Social democracy's ability to translate its ambition into reality, to follow the organizational thread, is also dependent on the party's historical ability to build strong movements with deep social anchors that offered significant potential for implementing its policy. ${ }^{5}$ My thesis is that these movements are, at present, eroding. Underlying these questions is the role of social democracy in the democratization of society.

\section{What is social democracy? An organizational definition}

When researchers try to describe what social democracy is, they have sometimes made use of a "broad" definition and a "narrow" one. One might say that these correspond to the aforementioned political and organizational levels. ${ }^{6}$

The narrow definition is based on the movement and its history. Its point of departure describes parties that have their roots in the (industrial) working class but at the same time are part of a larger movement. Trade unions have often been a central part of this movement, as have a number of other citizen organizations. The pattern varies from nation to nation. For a century, the working class in Nordic countries has been among the world's best organized. At its peak, the Swedish Social Democratic Party had 1.23 million members, in a country with a population of 8 million. Three-fourths of the party members were affiliated through the trade-union movement. For a long time, between 80 and 90 per cent of workers were members of the LO, the Swedish Trade Union Confederation. 
The party's Youth League was long dominated by the working class. There was a Women's League, and children were organized into the Young Eagles (Unga örnar). At its height, the so-called A-Press published some 30 social democratic daily newspapers. However, the social democratic family extended still further. Most important was the LO with more than 2 million members in the 1980s. The Workers' Educational Association (ABF) organized up to a hundred thousand study circles and lectures in a single year, and there were 1,000 people's houses around the country. Organizations such as the Swedish National Pensioners' Organization (PRO) and the Swedish Union of Tenants (Hyresgästföreningen), with hundreds of thousands of members, could also unquestionably be seen as part of the movement. Furthermore, an extensive cooperative consumer movement (KF) collaborated closely with the party as did the insurance company Folksam; HSB, a cooperative housing society; a film production company; advertising firms; and even a national chain of undertakers. Hundreds of thousands of members held positions in local politics. ${ }^{7}$ People could spend their whole lives, from cradle to grave, within the social democratic movement.

Even though Social Democratic Party influence in other Nordic countries has not been equally hegemonic, particularly in Finland and Denmark, social democracy has often been described as the "people's movement party". The parties can be characterized as socially imbedded institutions that are bearers of a specific political culture with clear democratic functions. The parties succeeded in organizing, mobilizing and socializing large groups that had previously been without political influence, first and foremost the working class. They contributed actively in creating a collective identity that became the basis for political activity. But they also contained a broader democratic potential, exceeding parliamentary institutions. In these milieus political demands and projects could be discussed, formulated and implemented between elections and the limits of politics could be challenged and widened.

\section{A political definition}

The broad definition of social democracy is, meanwhile, used in an attempt to single out some central features of a common reformist ideology that Social Democrats tried to translate into political action. Several terms inspired by the English Social Democrat Anthony Crossland sum it up: democracy, mixed economy, welfare state, equality. To this we usually add further specifications: on the one hand, corporatism, the institutionalized cooperation between capital, labour and state; on the other decommodification, a welfare state limiting the influence of markets. ${ }^{8}$

After the Second World War there was a sort of symbiosis between capital's wish for mass production and the people's wish for mass democracy. The strength of the economy, it was argued, depended on the welfare of the wage labourers. ${ }^{9}$ Economic development was driven by the 30 golden years of the post-war era, the longest and strongest boom in international capitalism. 
The Fordist welfare state developed into something that, from different political standpoints, was seen as a legitimate means by which the state could intervene in developments on behalf of democracy, social security and efficient markets. This intervention was seen as the solution to problems posed by capitalism and industrial society. ${ }^{10}$

But in that case, what distinguished the Social Democrats from other liberal and bourgeois forces? The latter were willing to put up with greater government intervention in exchange for stimulated productivity and an infrastructure appropriate to the new conditions of production. For the Social Democrats, Keynes made it possible to merge the interests of the working class with the goal of national growth. Economic planning, full employment, expansion of the welfare state with a clear general building programme, redistribution of resources to compensate for inequalities created by the market, greater equality - all this could be located, at least as stated goals, within the framework of the reformist project. ${ }^{11}$

In the Nordic countries, this was social democracy's greatest moment. In Sweden, Denmark and Norway, the party was in government for most of the 1950s and the 1960s. The working class was larger than ever, and three-fourths of the workers voted for the Social Democrats. In Finland, the situation was different, but in the 1970s the party gained influence both politically and organizationally.

A clever reform policy, which gained international notoriety, also caused significant portions of the middle class to share the reformist ambitions of the party. These fitted nicely into basic capitalist structures. Real departures from the market economy were yet to take place. Left-wing critics could, with strident bitterness, ask if a class compromise during an economic boom was all social democracy could accomplish.

Around 1970, things took a new, more radical course, especially where the Swedish welfare state was concerned. This can, to a large degree, be explained by a forceful shift in the spirit of the time. In Sweden, as elsewhere, the radicalization of the 1960s began with a youth movement characterized by international solidarity, new Marxist thinking and the appearance of a series of new social movements. These groups often criticized the Social Democrats for being bureaucratic and ideologically shallow. Instead of flagging after 1968, radicalization deepened and spread to additional sections of society, reaching a climax in the mid-1970s. The new women's movement also affected traditional women's associations, while the environmental movement succeeded in putting a stop to the expansion of Swedish nuclear power.

The workers' movement was also greatly affected. A notorious mining strike in 1969/70 triggered a wave of wildcat strikes, showing that central parts of the Swedish working class had joined the radical movement. At the same time, the social democratic workers' movement had never been larger, stronger, or better organized. Forty years in power had given the party experience, competence and self-confidence.

The reforms undertaken during these years were the most extensive ever implemented in Sweden. The manner in which the welfare state was organized 
was also of great importance. There was a striking degree of movement away from market dependence and toward an increasingly decommodified system. Everything from schools to day care to healthcare and care of the elderly was financed, owned and run by the public sector. The public sector became the spearhead of the social transformation. ${ }^{12}$

The best indication of how far the workers' movement was willing to go is the fact that the LO, which traditionally belonged to the less radical part of the workers movement, endorsed the proposal to create so-called employee funds. This proposal, had it had been implemented, would have meant that the major part of today's Swedish business sector would have been owned by trade unions. ${ }^{13}$ A similar development, if less dramatic, took place in the other Nordic nations.

The welfare regimes dominated by social democrats were far from unproblematic from a democratic point of view. They gained their power from structures organized by and for the masses. But they were led by bureaucracies. These were necessary if the parties were to function as mass organizations, in order to maintain ties to the masses - but also fulfilling their functions as parliamentary and corporate structures. As the years passed, and the workers' movement expanded its influence in various public agencies, critical voices were raised against a growing tendency towards autocracy. ${ }^{14}$

\section{The end of the golden years: politics and market}

As suddenly and unexpectedly as post-war social democracy had entered its golden age, suddenly - and unexpectedly, at least to many Social Democrats the decline set in. The long-lasting post-war boom petered out and a series of crises took its place. They were structural crises associated with great changes taking place in global capitalism. They had serious consequences for the employment rate and standards-of-living, and also led to extensive ideological shifts, not least in perceptions of the welfare state. Keynesian economic policy no longer worked. Stagflation, a combination of the two worst alternatives, inflation and economic stagnation, became a new phenomenon. ${ }^{15}$

A central tenet of the perception developed by bourgeois actors was the idea that politics had gained too much influence in the market. The solution was to let loose capitalism's self-healing powers, to emphasize the primacy of the market rather than politics. Once again, global economic developments greatly influenced democracy. In this context, the broad-based mass democracy associated with the welfare states was seen as a particularly great problem. Such a view stood in direct contraposition to the ideal that had come to be associated with post-war social democracy.

The issue of the relationship between market and democracy has, during recent years, received much attention and has been critically examined by leading social scientists. ${ }^{16}$ One focus concerns the gradual move away from redistributive mass democracy. 
The welfare state has shrunk and, to a large degree, been integrated into the market economy. The efforts toward decommodification, which had been notable in Sweden, have diminished or ceased altogether. A series of social regulations introduced during the post-war years has been repealed, as was the case where labour laws are concerned, which has resulted in precarity, wage dumping and the suppression of union rights. Another factor is the effect of growing state debt. This has contributed to a situation in which less and less of the state's resources could be used for financing new reforms.

Politicians also made important decisions divesting themselves of power over economic policy. In Sweden, this development began in the second half of the 1980s, with symbolically significant decisions to deregulate banking and to allow the exchange rate to float. In 1990, it was decided that the goal of a maximum of 2 per cent inflation was to take priority over low unemployment. When the national bank became independent of political regulation in 1999 , the politicians left crucial parts of macro-economic policy up to economists, often recruited from the banking sector.

Another sign of circumscribed space for extensive political intervention in the market economy is the trend towards increasing regulation of political activity. This is meant to tie the hands of supposedly irresponsible and meddlesome politicians. The Swedish budgetary legislation is an example of this. When Sweden joined the EU in 1994, many decisions were moved beyond the purview of democratically elected politicians. ${ }^{17}$

\section{Challenges to reformist politics}

Clearly all this hit social democracy hard. It was a challenge to their strongest card - Keynes and the attempts to regulate the market, using an expanding public sector as a lever for reducing market power. The crisis has also directly hit the movement's base, the industrial working class. This was, in part, a result of a significant decline in the number of industrial jobs; it was also in part because the common experience of shared struggle that had played such a large part in the creation of the workers' movement had become somewhat motheaten during the golden years. It was further diluted as the trade unions were weakened and increasingly attacked.

It was a rude awakening. In one country after another, the Social Democrats have been forced - or have chosen - to adapt to these new conditions, usually as a result of acute political and/or economic crises. Instead of nostalgically looking backwards towards the policies of a different era, European Social Democrats, initially inspired by New Labour, entered into a dialogue concerning the important issues of this new era, such as globalization, information technology and individualization. In order to participate in this discourse, they accepted its fundamental conditions: monetarism; a freer, deregulated market; a balanced budget; low inflation rather than less unemployment; diminished income transfer (that is, greater gaps in income); and privatization. The welfare 
system and the public sector had to be streamlined, slimmed down, shrunk but not abolished. Capitalism was to be streamlined and the Social Democrats were once again to be the bearers of modernism. ${ }^{18}$

At the same time, the EU was seen as an opportunity to implement part of the programme that seemed impossible to accomplish at the national level. However, the hopes raised by the social dimensions of various EU treaties, from Amsterdam and Lisbon to Gothenburg 2017, have only to a very small extent translated into binding agreements. It is a common perception among researchers that the crucial obstacle hampering the realization of a social Europe is built into the structures of the EU. As a matter of fact, according to the Greek social scientist Gerassimo Moschonas, the EU undermines three of the classic, fundamental features of social democracy: faith in the state, faith in the primacy of politics and a welfare policy related to the working class. ${ }^{19}$

In the introduction, social democracy was sketched out in general terms. This broad definition was an attempt to capture some central features of a common reformist ideology. It was based on the assumption that Social Democrats and capitalists shared an interest in creating the best possible conditions for economic growth including both state regulation and the welfare state. This, in turn, could take forms that allowed politics to limit the power of capital. Clearly the preconditions for this platform have been undermined. Today, to put it mildly, capital's wish to join in common projects with the workers' movement is minimal, and social democracy's programme for curbing the market is not particularly concrete. After the financial crisis of 2008-2009, the European Social Democrats were to pay the price for this.

The crisis of the 1930s had been the beginning of the social democrat success story. An important reason was that Social Democrats succeeded in offering a successful alternative to the economic liberalism of the time. The Social Democrats had no such alternative to propose in 2008. Clearly the EU has played an important role in this context.

The EU has gradually developed from being an economic-political union to being primarily a tool for the implementation of neo-liberal policy. In the Maastricht and Lisbon treaties, monetarism was codified as a foundation for EU economic policy. When the euro was introduced, most countries were formally bound to implement a monetary economic policy and far-reaching market reforms. With the arrival of the troika - which includes not only the ECB and the EU Commission but also the IMF, an authority over which the EU has no control at all - the final say in European politics has been placed with a hydra without formal judicial or political standing and beyond democratic oversight. $^{20}$

The post-financial crisis policy, imposed by Brussels and Frankfurt with an iron hand, has torn Europe apart. The severe cutbacks forced upon those in the periphery of the monetary union have led to income gaps and social misery of a kind that had not been seen in Europe for decades - without succeeding to put an end to the economic turbulence that began with the financial crisis nearly ten years ago. 
In none of these cases have the Social Democrats raised objections. On the contrary, all the leaders of the European social democracy have assented to this development. In many cases, indeed, they have been the ones to crack the whip over countries that could not sufficiently meet the demands of the market. As is well known, Greece is an especially pitiful example. The European Social Democrats have acted in like manner when it comes to the EU's other great failure, the refugee question. The refugee crisis, to a substantial extent a result of EU intervention in the Middle East - from the invasion of Iraq and onwards - is a humanitarian and social catastrophe. It is also an expression of a moral collapse on the part of the EU, which has not only refused to take responsibility for preventing further human suffering, but whose cynical behaviour has further contributed to strengthening the rapidly growing xenophobic forces in Europe. $^{21}$

Social Democrats have simply abandoned what was, during their years of success, their strongest talking point - the prioritizing of political concerns over market interests. They have consciously refrained from proposing any kind of alternative policy and have actively contributed to tying their own hands. And they have made a virtue out of this necessity. By concentrating entirely on trying to win over the middle class, Social Democrats have tried to erase differences between the political blocs. In countries like Germany and Finland, Social Democrats have formed coalitions with bourgeois parties. In other countries, such as Spain and the Nordic countries, right- and left-wing parties take turns being in power, without either making significant political changes. ${ }^{22}$

\section{A decreasing movement}

But the narrow definition of social democracy has also been affected by the neoliberal turn. The space in which traditional mass parties - not least the Social Democrats - operate has changed fundamentally. ${ }^{23}$ This neoliberal turn created a larger gap between citizens and their representatives. What had previously made the party members essential - the election of party leaders, financing activities, input into policy formation and implementation - is no longer necessary. Sponsorships and state subsidies have made membership fees less important to party budgets. Public surveys have replaced input from membership organizations. Media and PR consultants spread the parties' messages more effectively and directly than the members can.

Party leaders are being recruited from an increasingly narrow social circle, different from those of party members and voters. Party leadership has become professionalized and career paths become more and more alike from party to party. The loyalties of the leaders also increasingly lie with the political class. The tendency to form a new political class is reinforced by a general consensus on policy, or from there being, at least, little scope for a change of political course. ${ }^{24}$ A fight for the middle has, of course, characterized politics for the last decades. Engagement in political parties has dwindled. Voter loyalty to a party has also weakened significantly, as it has become increasingly common 


\section{2}

to change party preferences between elections. The post-war mass parties have developed into professional "catch-all-parties". ${ }^{25}$

This development has had obvious socio-economic consequences. Those who first and foremost have lost confidence in politics and have distanced themselves most from political participation are those who are hardest hit by the growing social gaps that have developed in the wake of policy changes. The emergence of populist right-wing parties can, to a certain degree, be seen as a reaction to this development. This, of course, has particular consequences for the social-democratic mass parties. ${ }^{26}$ Large sectors of what used to be social democracy's base of popular movements have weakened, even eroded.

There are several reasons for this. One has to do with changes in class structure and social composition. The size of the industrial working class that had formed the social base for social democracy has diminished greatly. This is due to the almost complete disappearance of the many factory towns - often built around one factory - in which social democracy had been hegemonic. Voting according to class, with two-thirds of the LO's members voting social democrat and most of the remainder voting for other left-wing parties, has dwindled in the new millennium. In the election of 2018 only 40 per cent of the LO's members voted for Social Democrats.

The social composition of the party's membership has changed. Workers are very much underrepresented in political congregations of party members, and even more as a proportion of voters. Their relative scarcity becomes more palpable the further up the hierarchy one goes. The proportion of "political broilers" - party leaders who have never been part of the workforce - has grown dramatically. ${ }^{27}$

For a long time, values based on the workers movement's egalitarian ideals were dominant, even within the right-leaning strata of the Social Democratic Party. As the party's recruitment base changed, the hold these values have on the party has loosened. This may also be in response to the party's policies becoming increasingly adapted to the market. When they leave politics, socialdemocratic top politicians continue their careers within the private sector, something that was unimaginable a few generations ago.

Another central factor is the weakening of the social movements from which social democracy sprang. Sweden's LO has lost half a million members over the last ten years. For the first time since the 1930s, the proportion of organized workers in the party is below 70 per cent. Social-democratic cooperatives have been commercialized, People's Houses to a large extent have been sold or shut down, and the social-democratic press has gone bankrupt.

All the parties' memberships have collapsed. A crucial change took place when the LO, in the early 1990s, abolished collective membership in the Social Democratic Party. Until then, the party had had more than 1.2 million members. In 1992, the number was still a quarter of a million. Today, the number has sunk to 90,000 , and the average age of its members is 60 . With the partial collapse of the social-democratic youth association (SSU), the party lost what had traditionally been its most important source of leadership recruits 
for different leadership levels. In Finland, social-democratic membership has shrunk by more than a half over a couple of decades, and the workers movement's "red machines" have suffered a severe loss of power. ${ }^{28}$

The EU's two major failures - first, its inability to hold the Union together socially and economically after the financial crisis of 2008 and, second, the migration question - led to the consequences mentioned previously. In Sweden, the Social Democrats have found themselves trapped within frameworks created by these two issues.

While the Swedish economy has grown in recent years, Sweden's economic and social gaps have increased more than in most OECD countries. The series of tax reforms that were implemented by social-democratic governments before 2006 and by the conservative government between 2006 and 2014 benefited primarily society's upper echelons. ${ }^{29}$

At the same time, the foundation of the solidaric welfare state has eroded. Social security increases, as well as increases in subsidies such as child benefits, have lagged behind inflation. ${ }^{30}$ The continued privatization of care and education has undermined the political control of a previously public-run welfare apparatus and has created new fissures, especially within the educational sector. The return of a social democratic government in 2014 merely led to minor adjustments of this policy.

The most spectacular outcome of the 2014 election was the rise of the right-wing, populist Sweden Democrats. They succeeded in doubling their votes to 13 per cent, which meant that none of the traditional political blocs was able to form a majority. Unlike their sister parties in Denmark and Norway, the Sweden Democrats have their roots in openly racist and pro-Nazi organizations. ${ }^{31}$ Since the late 1990s, a new generation of young leaders has successfully managed to build an effective party organization, starting from local strongholds in southern Sweden. Xenophobia and anti-immigration have been the party's main ideological platforms and the main reasons they have been able to win votes. With increasing parliamentary influence, the party has made efforts to downplay its more openly racist rhetoric, expelling some of its most enthusiastic representatives. The party has also lately tried to stress the national-conservative features of its programme, in imitation of similar trends in Poland and Hungary. The Sweden Democrats' economic and welfare policies, in fact, resembled those of the Conservative Party. For a long time there was a de facto agreement between the traditional parliamentary parties that the Sweden Democrats should be isolated; all were to refrain from involving them in negotiations. This was one reason why Sweden's right-wing parties accepted the red-green coalition in 2014.

The huge numbers of refugees in 2014 and 2015 - Sweden received 80,000 in 2014, 160,000 in 2015 - changed the political situation almost overnight. Before October 2015, there was broad consensus that Swedes were prepared to "open their hearts" - to quote former Conservative Party leader Fredrik Reinfeldt. Initially, only Sweden Democrats criticized the massive immigration. When the party started to grow and shortcomings in the organization 


\section{Kjell Östberg}

of the reception of refugees became obvious, most leading parties, including the Social Democrats, agreed to put an immediate stop to the influx and readjust Swedish immigration policy to conform to the EU's minimum criteria. This change was more than a formal adaptation to new conditions. It was accompanied by a rise in anti-immigrant sentiments, anti-Muslim agitation and demands from the traditional parties - including the governing Social Democrats - for tougher legislation against what were claimed to be crimes committed by immigrants. ${ }^{32}$

Just before the election of 2018, the Social Democrats' policies took a turn to the right, not only concerning immigrant-related legislation but also in terms of attitudes towards law and order. In 2017, Sweden was hit by a terrorist attack. At the same time, attention was drawn to a series of fatal shootings that became associated with criminal gangs of immigrant background. Now the Sweden Democrats were no longer alone in demanding more severe penalties for crimes that were alleged to be linked to immigration.

Clearly one reason for the change in policy was the threat posed to both Social Democrats and Conservatives by the Sweden Democrats. As could have been predicted by looking at experiences in other countries, the change of tactics did not work. The Sweden Democrats continued to grow at the expense of these two parties in particular. The result of the most recent election in 2018 confirms this conclusion. The Social Democrats' votes fell to 28 per cent, their lowest result since the introduction of universal suffrage in 1921. The Conservatives lost even more, falling by 3.5 per cent. Meanwhile, the Sweden Democrats reached 17.5 per cent, an increase of almost 5 per cent.

A majority of the working class is not voting left any more. Thirty years ago 70 per cent of the working class voted Social Democrat (and another 10 per cent Communist). In 2014, 53 per cent of the members of the LO voted Social Democrat; in 2018, only 40 per cent (and another 10 per cent for the Left party). ${ }^{33}$ The outcome changed the political landscape in several regards. The result led to a stalemate between the two traditional political blocs. To be able to take over the government, the Conservatives together with the Christian Democrats were prepared to pass the demarcation line that until then existed between the traditional political parties and the xenophobic right-wing populists and form a government with a de facto support of the Sweden Democrats.

This attempt was blocked by the two liberal parties who broke up a longtime alliance with the Conservatives and decided to support a social democratic government. The support was not without costs. The Social Democrats had to accept a political agreement forcing the government to carry out a robust neoliberal programme, including increased privatization of the welfare sector, lower taxes for the wealthy and higher rents for tenants. Perhaps most controversial was an agreement that threatened to weaken the influence of the trade unions.

The political development of the last few decades has been discussed mainly from a top-down perspective. Few of the reforms and political course changes implemented by the Social Democrat leaders were instituted due to pressure 
from below. On the contrary, each departure from traditional social-democratic policy has met with extensive protests. When the first step was taken toward a neoliberal policy focused on deregulation in the 1980s, the result was the so-called War of the Roses, with the LO leading the critical charge. A majority of the social-democratic electorate voted against joining the EU in the 1990s. The new, individual-based and market-oriented pension system that was implemented at the same time failed to get support from any of the socialdemocratic party congresses that discussed the issue. In spite of its great efforts, the social-democratic government did not manage to push through Sweden's inclusion in the European Monetary Union (EMU) after the turn of the 21st century. Over the last years, opposition to further erosion of the public sector has primarily focused on education, healthcare and other care activities and the emergence of large, for-profit organizations within the tax-funded welfare sector. $^{34}$

The outcome of the 2018 elections has created further protests among trade unions and rank-and-file members of the party. However, this has not had any deeper impact on the party leadership. It is obvious that the Swedish Social Democrats have chosen to continue the road also taken by several other European Social Democrats. There are few reasons to believe that the results would be different in Sweden.

In Finland, the Social Democrats after the 2019 parliamentary elections were able to form a centre-left government. The party made some gains and became the largest, but only got 17.7 per cent of the vote and came in just slightly ahead of the right populist True Finns. The result is far below the vote levels of what the party used to attract a couple of decades ago.

The combination of the strengthening positions of the global market economy, the declining space for political decisions, the decreasing ambitions of the social democratic leadership and the gradual vanishing of the movement that once constituted the democratic core of the social democratic movement has led to a fundamentally altered condition for political mobilization and actions and, by extension, for the future of democracy.

\section{Notes}

1 Misgeld, Molin \& Åmark 1992.

2 Waele, Escalona \& Vieira 2013, 17-18.

3 Östberg 2012, 205.

4 Schmidt 2016, 251-252.

5 Östberg 2012, 207-208.

6 Moschonas 2002, 64.

7 Östberg 2018, 403-244.

8 Esping-Andersen 1990.

9 Crouch 2004.

10 Judt 2012, 324-359.

11 Sejersted 2011.

12 Östberg 2017, 36-37.

13 Östberg 2012. 
14 Östberg 2008, 406-407.

15 Notermans 2000.

16 Mair 2013.

17 Östberg 2012, 222.

18 Andersson 2010.

19 Moschonas 2009.

20 Ibid.

21 Barlai 2017.

22 Schmidt 2016.

23 Mair 2013.

24 Hermansson 2010, Bergström \& Järliden Bergström 2013, Östberg 2014.

25 This process was discussed in a theme issue of Statsvetenskaplig tidskrift in 2010. Statsvetenskaplig tidskrift, 112:2.

26 Östberg 2018, 418-419.

27 Garsten, Rothstein \& Svallfors 2015.

28 Östberg 2018, 412-418.

29 OECD 2019.

30 Lindbom 2011.

31 Jungar 2017.

32 Dahlstedt \& Neergaard 2016.

33 VALU 2018.

34 Östberg 2017, 62.

\section{References}

Andersson, Jenny, 2010: The Library and the Workshop. Social Democracy and Capital in an Age of Knowledge. Stanford: Stanford University Press.

Barlai, Melani, Fähnrich, Birte, Griessler, Christina \& Rhomberg, Markus (eds.) 2017: The Migrant Crisis. European Perspectives and National Discourses. Zürich: Lit Verlag.

Bergström, Jeanette \& Järliden Bergström, Åsa-Pia, 2013: Makteliten. Klyftorna består. Stockholm: LO.

Crouch, Colin, 2004: Post-Democracy. Cambridge: Polity Press.

Dahlstedt, Magnus \& Neergaard, Anders, 2016: "Crisis of Solidarity? Changing Welfare and Migration Regimes in Sweden" in Critical Sociology, 45:1, 121-135.

Esping-Andersen, Gøsta, 1990: The Three Worlds of Welfare Capitalism. Cambridge: Polity Press.

Garsten, Christina, Rothstein, Bo \& Svallfors, Stefan, 2015: Makt utan mandat. De policyprofessionella $i$ svensk politik. Stockholm: Dialogos.

Hermansson, Jörgen \& Beckman, Ludvig, 2010: Regeringsmakten i Sverige. Ett experiment $i$ parlamentarism 1917-2009. Stockholm: SNS förlag.

Judt, Tony, 2012: Postwar: A History of Europe Since 1945. New York: Penguin Press.

Jungar, Ann-Cathrine, 2017: "Continuity and Convergence: Populism in Scandinavia" in Peter Nedergaard \& Anders Wivel (eds.) The Routledge Handbook of Scandinavian Politics. London: Routledge.

Klaus Misgeld, Karl Molin \& Klas Åmark (eds.) 1992: Creating Social Democracy. A Century of the Social Democratic Labor Party in Sweden. University Park: Pennsylvania State University Press.

Lindbom, Anders, 2011: Systemskifte? den nya svenska välfärdspolitiken. 1. uppl. Lund: Studentlitteratur.

Mair, Peter, 2013: Ruling the Void: The Hollowing of Western Democracy. London: Verso. 
Moschonas, Gerassimos, 2002: In the Name of Social Democracy. The Great Transformation, 1945 to the Present. London: Verso.

Moschonas, Gerassimos, 2009: "Reformism in a 'Conservative' System. The European Union and Social Democratic Identity” in John Callaghan (ed.) In Search of Social Democracy: Responses to Crisis and Modernisation. Manchester: Manchester University Press.

Notermans, Ton, 2000: "Europeanization and the Crisis of Scandinavian Social Democracy" in Robert Geyer, Christine Ingebritsen \& Jonathon Wayne Moses (eds.) Globalization, Europeanization and the End of Scandinavian Social Democracy? London: Palgrave Macmillan, 23-44.

OECD, 2019: OECD Economic Surveys: Sweden 2019. Paris: OECD Publishing. https://doi. org/10.1787/c510039b-en.

Östberg, Kjell, 2008: “Sweden and the Long'1968'. Break or Continuity?” in Scandinavian Journal of History, 33:4, 339-352.

Östberg, Kjell, 2012: "Swedish Social Democracy after the Cold War. Whatever Happened to the Movement?" in Ingo Schmidt \& Bryan Evans (eds.) Social Democracy after the Cold War. Edmonton, AB: AU Press.

Östberg, Kjell, 2014: "Politikens ändrade villkor" [Changing Conditions of Politics] in Anders Ivarsson Westerberg et al. (eds.) Det långa 1990-talet. När Sverige förändrades. Umeå: Boréa.

Östberg, Kjell, 2017: "Den solidariska välfärdsstaten och förändringarna i den politiska dagordningen" in Torsten Kjellgren (ed.) När skiftet äger rum. Vad händer när den politiska dagordningen ändras. Stockholm: Tankesmedjan Tiden.

Östberg, Kjell, 2018: "När ingen längre kokar kaffet" in Henrik Meinander, Petri Karonen \& Kjell Östberg (eds.) Demokratins drivkrafter. Kontext och särdrag i Sveriges och Finlands demokratier 1890-2020. Stockholm: Appell förlag.

Schmidt, Ingo (ed.) 2016: The Three Worlds of Social Democracy: A Global View. London: Pluto Press.

Sejersted, Francis, 2011: The Age of Social Democracy: Norway and Sweden in the Twentieth Century. Princeton, NJ: Princeton University Press.

Statsvetenskaplig tidskrift, 2010, 112:2.

VALU. SVT:s valundersökning 2018, 2018: www.svt.se/omoss/media/filer_public/ 5c/17/5c17fc91-31c4-4e0a-a17f-b42318edf4a4/valuresultat_riksdagsval_pk_2018_ vagda_0912.pdf.

Waele, Jean-Michel de, Escalona, Fabien \& Vieira, Mathieu (eds.) 2013. The Palgrave Handbook of Social Democracy in the European Union. Basingstoke: Palgrave Macmillan. 